\title{
Periungual lesions secondary to chemotherapy with docetaxel
}

\section{Zmiany w obrębie aparatu paznokciowego w przebiegu chemioterapii docetakselem}

\author{
Dawid Sigorski', Agnieszka Markiewicz², Agnieszka B. Owczarczyk-Saczonek², Paweł Różanowski, \\ Anna Kułakowska', Aneta Lebiedzińska', Waldemar J. Placek²
}

\author{
'Department of Oncology, University of Warmia and Mazury, Olsztyn, Poland \\ 2Department of Dermatology, Sexually Transmitted Diseases and Clinical Immunology, University of Warmia and Mazury, Olsztyn, \\ Poland \\ ${ }^{3}$ Department of Chemotherapy, Wielkopolskie Centrum Onkologii, Poznan, Poland \\ 'Katedra Onkologii, Uniwersytet Warmińsko-Mazurski, Olsztyn, Polska \\ ${ }^{2}$ Klinika Dermatologii, Chorób Przenoszonych Drogą Płciową i Immunologii Klinicznej, Uniwersytet Warmińsko-Mazurski, Olsztyn, \\ Polska
}

${ }^{3}$ Oddział Chemioterapii, Wielkopolskie Centrum Onkologii, Poznań, Polska

\author{
CORRESPONDING AUTHOR/ \\ ADRES DO KORESPONDENCJI: \\ lek. Agnieszka Markiewicz \\ Klinika Dermatologii, \\ Chorób Przenoszonych \\ Drogą Płciową \\ i Immunologii Klinicznej \\ ul. Wojska Polskiego 30 \\ 10-229 Olsztyn, Polska \\ tel. +48602658879 \\ e-mail: agaen@wp.p
}

\begin{abstract}
Chemotherapy is a basic treatment method of neoplasms at a systemic stage. Chemotherapy regimens including docetaxel are commonly used in every day clinical practice. Docetaxel is a chemotherapeutic agent that causes skin toxicity among other side effects. It involves alopecia and periungual lesions. The latter may cause pain as well as discomfort, and constitute a cosmetic problem. Sometimes they may lead to termination of the therapy due to negative effects on the quality of life and everyday activities. The aim of the article is to present clinical problems of patients undergoing chemotherapy with docetaxel that experience periungual lesions, and show treatment methods from a dermatologist's perspective. Moreover, prophylactic methods that prevent appearance of severe lesions are presented.
\end{abstract}

\section{STRESZCZENIE}

Chemioterapia jest podstawową metodą leczenia nowotworów w stadium uogólnienia. Schematy chemioterapii zawierające docetaksel są powszechnie stosowane w codziennej praktyce klinicznej. Docetaksel jest chemioterapeutykiem, który oprócz innych objawów niepożądanych powoduje toksyczność skórną, m.in. łysienie oraz zmiany okołopaznokciowe. Zmiany okołopaznokciowe mogą wywoływać ból, dyskomfort oraz stanowić problem kosmetyczny. Czasami są przyczyną zakończenia terapii z powodu negatywnego wpływu na jakość życia i codzienne funkcjonowanie. Celem pracy jest przedstawienie problemów klinicznych pacjentów poddanych chemioterapii docetakselem, u których wystąpiły zmiany okołopaznokciowe, a także metod leczenia z punktu widzenia dermatologa. Autorzy zaproponowali również metody zapobiegania powstawaniu zmian o dużym nasileniu.

Key words: chemotherapy, docetaxel, periungual lesions.

Słowa kluczowe: chemioterapia, docetaksel, zmiany aparatu paznokciowego. 


\section{INTRODUCTION}

Chemotherapy is a basic treatment method of neoplasms at a systemic stage. Chemotherapy regimens including docetaxel are commonly used in every day clinical practice. Docetaxel, a cytotoxic drug belonging to the group of taxanes, is phase-specific mitosis inhibitor that is extracted from needles of the English yew. By binding to $\beta$-tubulin, it inhibits depolymerisation of microtubules. It is used in mono- and poly-therapies of many malignant cancers, including prostatic carcinoma, lung cancer, stomach cancer, breast cancer, or head and neck cancers [1]. In case of prostatic cancer, it is only used as palliative treatment, whereas in other cancers it is also used pre and/or post surgeries (neoadjuvant/inductive and/ or adjuvant/complementary treatment respectively). The group of taxanes includes also paclitaxel and cabazitaxel. The former is a commonly used cytotoxic agent in treatment of many malignant cancer, however, it has no application in the treatment of prostatic cancer, whereas the latter is registered only to be used in case of prostatic cancer, but it is not used in Poland due to the negative opinion of the Agency for Health Technology Assessment and Tariff System and lack of financial benefits associated with that.

In Poland, prostatic cancer is the most popular cancer among men and constitutes the second cause of death due to a neoplastic disease among them. The incidence rate for prostatic cancer in Poland is continually increasing. The most important risk factors to develop the disease are age and genetic predispositions $[2,3]$. A mere hormone therapy had been a basic treatment method for systemic prostatic cancer for a number of years. Results of subsequent phase III studies have been gradually changing this treatment standard.

Currently docetaxel is used in so-called hormone-independent and hormone-dependent (proper terms - respectively - resistant and sensitive to castration) prostatic cancer with metastases. In the first case, it constitutes basic treatment option when the disease moves to hormone-independent stage (so-called castration-resistance/hormone-independence) that occurs after about 2 years of hormone therapy (with analogues or antagonists of gonadotropin-releasing hormone, LHRH, and/or nonsteroidal antiandrogenes). In phase III study, TAX 327, patients with a diagnosed prostatic cancer treated with docetaxel reached the overall survival median of 18.9 months. The most common adverse events of the treatment in grade 3 and 4 according to CTC (Common Toxicity Criteria) include fatigue and neutropenia. Periungual lesions in all toxicity grades occurred in $30 \%$ of patients when the drug was used every 3 weeks, and in $37 \%$ of patients when the drug was used every week.

\section{WPROWADZENIE}

Chemioterapia jest podstawową metodą leczenia nowotworów w stadium uogólnienia. Schematy chemioterapii zawierające docetaksel są powszechnie stosowane w codziennej praktyce klinicznej. Docetaksel to cytostatyk należący do grupy taksanów (taksoidów), fazowo specyficzny inhibitor mitozy otrzymywany z igieł cisu pospolitego. Poprzez łączenie z $\beta$-tubuliną hamuje depolimeryzację mikrotubul. Jest stosowany w mono- lub politerapii wielu nowotworów złośliwych, takich jak rak gruczołu krokowego, płuca, żołądka, piersi oraz nowotwory głowy i szyi [1]. W raku gruczołu krokowego ma zastosowanie wyłącznie w leczeniu paliatywnym, natomiast w innych nowotworach także przed- i/lub pooperacyjnym (odpowiednio neoadiuwantowym lub indukcyjnym i/lub adiuwantowym lub uzupełniającym). Do grupy taksanów należą również paklitaksel i kabazytaksel. Pierwszy jest cytostatykiem powszechnie wykorzystywanym w leczeniu wielu nowotworów złośliwych, jednak nie ma zastosowania w terapii raka gruczołu krokowego, podczas gdy drugi jest zarejestrowany wyłącznie w raku gruczołu krokowego, ale nie jest w Polsce stosowany z powodu negatywnej opinii Agencji Oceny Technologii Medycznych i Taryfikacji oraz związanego z tym braku refundacji.

Rak gruczołu krokowego jest w Polsce najczęstszym nowotworem u mężczyzn i stanowi u nich drugą przyczynę zgonu z powodu choroby nowotworowej. Współczynnik zachorowalności na raka gruczołu krokowego w Polsce stale wzrasta. Najważniejszymi czynnikami ryzyka zachorowania na ten typ nowotworu są wiek oraz predyspozycje genetyczne [2, 3]. Samodzielna hormonoterapia przez wiele lat stanowiła podstawową metodę leczenia uogólnionego raka gruczołu krokowego. Wyniki kolejnych badań klinicznych III fazy stopniowo zmieniały ten standard leczenia.

Obecnie docetaksel ma zastosowanie w tzw. hormononiezależnym i hormonozależnym (właściwsze określenia to odpowiednio - opornym i wrażliwym na kastrację) raku gruczołu krokowego z przerzutami. W pierwszym przypadku stanowi podstawową opcję leczenia po przejściu choroby w stadium niezależne od hormonów (tzw. oporność na kastrację lub hormononiezależność), co występuje średnio po 2 latach terapii hormonalnej (analogami lub antagonistami gonadoliberyny - LHRH i/lub niesteroidowymi antyandrogenami). W badaniu III fazy TAX 327 pacjentów z rozpoznaniem raka gruczołu krokowego leczonych docetakselem osiągnęło medianę przeżycia całkowitego 18,9 miesiąca. Do najczęstszych działań niepożądanych leczenia w stopniu 3 i $4 \mathrm{wg}$ skali CTC (Common Toxity Criteria) należą zmęczenie oraz neutropenia. Zmiany aparatu paznokciowego 
According to the protocol of the above-mentioned study, docetaxel is used intravenously at the dose of $75 \mathrm{mg} / \mathrm{m}^{2}$ every 3 weeks together with prednisone administered orally at the dose of $10 \mathrm{mg} /$ day, every day, for an entire period of chemotherapy. Standardly, when treating castration-resistance prostatic cancer, 6-10 cycles of chemotherapy are added [4]. It is believed that adding over 6 cycles (but not more than 10) in hormone-resistant cancer additionally extends the overall survival. In case of patients with a slightly worse general condition, it is allowed to administer the drug every 2 weeks at the dose of $50 \mathrm{mg} / \mathrm{m}^{2}$ (also up to the maximum dose of $750 \mathrm{mg} / \mathrm{m}^{2}$ ) [5], whereas in patients with contraindications to take glucocorticosteroids (e.g. diabetes) it is allowed to administer docetaxel without simultaneous use of prednisone.

In recent years study results have been published (CHAARTED and STAMPEDE), in which it was showed that the survival of patients with initially systemic hormone-sensitive prostatic cancer that received chemotherapy with docetaxel in combination with antiandrogene hormone therapy (so-called chemohormonal therapy) as the first-line therapy was significantly prolonged. Patients in the experimental group received antiandrogene therapy (gonadoliberin analogue) and 6 cycles of docetaxel at the dose of $75 \mathrm{mg} / \mathrm{m}^{2}$; in the standard arm it was only hormone therapy with antiandrogene effects. Patients receiving chemohormonal therapy that were in a group of the highest risk of death (massive metastases) lived 17 months longer (median survival rate: 49 vs. 32 months). According to the published information, periungual lesions occurred only $1 \%$ of the population and had toxicity grade from 3 to $5[6,7]$; however, from the authors' clinical practice it stems that frequency of skin and periungual lesions is higher in the described population, especially since the moment when docetaxel generics were introduced and started to be widely used.

Docetaxel is a chemotherapeutic that causes skin toxicity. It includes alopecia and periungual lesions. These lesions are often reported by patients as adverse events of oncological treatment based on systemic therapy involving cytotoxic agents. They cause pain, discomfort, and constitute cosmetic problems. Sometimes they may be to termination of the therapy due to negative effects on the quality of life and every activity. In addition, taxanes cause peripherial neuropathy, what only adds to the negative treatment evaluation by patients. When severe skin reactions appear, according to the summary of product characteristics the drug dose should be decrease and/or the administration of subsequent chemotherapy cycle should be postponed till the moment when the intensity of adverse events falls down to a level that would allow for therapy continuation. Nail ap- we wszystkich stopniach toksyczności występowały u $30 \%$ pacjentów w przypadku stosowania leku co 3 tygodnie oraz u $37 \% \mathrm{w}$ przypadku stosowania co tydzień. Zgodnie z protokołem tego badania docetaksel stosuje się dożylnie, w dawce $75 \mathrm{mg} / \mathrm{m}^{2}$ co 3 tygodnie, razem $\mathrm{z}$ prednizonem podawanym doustnie w dawce $10 \mathrm{mg} /$ dobę, codziennie, przez cały czas trwania chemioterapii. Standardowo w leczeniu opornego na kastrację raka prostaty podaje się 6-10 cykli chemioterapii [4]. Uważa się, że podanie więcej niż 6 cykli (ale maksymalnie 10 ) w tym typie raka wpływa na dodatkowe wydłużenie przeżycia całkowitego. U pacjentów w nieco gorszym stanie ogólnym dopuszcza się podawanie leku co 2 tygodnie w dawce $50 \mathrm{mg} /$ $\mathrm{m}^{2}$ (również do dawki maksymalnej $750 \mathrm{mg} / \mathrm{m}^{2}$ ) [5], a u chorych z przeciwwskazaniami do stosowania glikokortykosteroidów (np. cukrzyca) dopuszcza się podawanie docetakselu bez jednoczesnego stosowania prednizonu.

W ostatnich latach opublikowano wyniki badań (CHAARTED i STAMPEDE), w których stwierdzono znaczące wydłużenie przeżycia chorych z pierwotnie uogólnionym hormonowrażliwym rakiem gruczołu krokowego otrzymujących chemioterapię docetakselem połączoną z antyandrogenową terapią hormonalną (tzw. chemiohormonoterapię) w pierwszej linii leczenia. Pacjenci w grupie eksperymentalnej otrzymywali terapię antyandrogenową (analog gonadoliberyny) oraz 6 cykli docetakselu w dawce $75 \mathrm{mg} / \mathrm{m}^{2}$, a $\mathrm{w}$ ramieniu standardowym tylko hormonoterapię o działaniu antyandrogenowym. Pacjenci z grupy najwyższego ryzyka zgonu (z masywnymi przerzutami) otrzymujący chemiohormonoterapię żyli 17 miesięcy dłużej (mediana przeżycia 49 vs 32 miesiące). Zmiany okołopaznokciowe wg publikacji występowały tylko u $1 \%$ pacjentów w stopniach toksyczności od 3 do $5[6,7]$, jednak z praktyki klinicznej autorów wynika, że częstość występowania zmian skórnych i okołopaznokciowych w opisywanej populacji jest większa, zwłaszcza od momentu wprowadzenia i powszechnego stosowania leków generycznych zamiast oryginalnego docetakselu.

Docetaksel jest chemioterapeutykiem, który powoduje także toksyczność skórną, m.in. łysienie oraz zmiany okołopaznokciowe. Zmiany te są często zgłaszane przez pacjentów jako działanie niepożądane leczenia onkologicznego opartego na terapii ogólnej z zastosowaniem cytostatyków. Powodują one ból, dyskomfort oraz stanowią problem kosmetyczny. Czasami mogą być przyczyną zakończenia terapii z powodu negatywnego wpływu na jakość życia i codzienne funkcjonowanie. Taksany wywołują też neuropatię obwodową, co dodatkowo przyczynia się do negatywnej oceny leczenia przez chorego. W przypadku odczynów skórnych o ciężkim przebiegu dawkę leku zgodnie $\mathrm{z}$ charakterystyką pro- 
Table I. Frequency of ungual and periungual lesions during a therapy with docetaxel

Tabela I. Częstość występowania zmian paznokciowych i okołopaznokciowych w trakcie terapii docetakselem

\begin{tabular}{|c|c|c|c|}
\hline Cancer/Nowotwór & $\begin{array}{l}\text { Chemotherapy regimen/ } \\
\text { Schemat chemioterapii }\end{array}$ & $\begin{array}{c}\text { Docetaxel dose } \\
{\left[\mathrm{mg} / \mathrm{m}^{2}\right] /} \\
\text { Dawka docetakselu } \\
{\left[\mathrm{mg} / \mathrm{m}^{2}\right]}\end{array}$ & $\begin{array}{l}\text { Frequency of ungual/periungual lesions } \\
\text { grade 3-4 according to CTC/Częstość } \\
\text { występowania zmian paznokciowych lub } \\
\text { okołopaznokciowyh w stopniu 3-4 wg CTC }\end{array}$ \\
\hline Breast cancer/Rak piersi & Docetaxel/Docetaksel & 100 & $2.6 \%$ \\
\hline Breast cancer/Rak piersi & $\begin{array}{l}\text { Docetaxel, doxorubicin/ } \\
\text { Docetaksel, doksorubicyna }\end{array}$ & 75 & $0.4 \%$ \\
\hline Breast cancer/Rak piersi & $\begin{array}{l}\text { Docetaxel, capecitabine/ } \\
\text { Docetaksel, kapecytabina }\end{array}$ & 75 & $2 \%$ \\
\hline Breast cancer/Rak piersi & $\begin{array}{c}\text { Docetaxel, doxorubicin, } \\
\text { cyclophosphamide/Docetaksel, } \\
\text { doksorubicyna, cyklofosfamid }\end{array}$ & 75 & $0.4 \%$ \\
\hline Lung cancer/Rak płuca & Docetaxel/Docetaksel & 75 & $0.8 \%$ \\
\hline Lung cancer/Rak płuca & $\begin{array}{l}\text { Docetaxel, cisplatin/ } \\
\text { Docetaksel, cisplatyna }\end{array}$ & 75 & $0.7 \%$ \\
\hline $\begin{array}{l}\text { Stomach cancer/Rak } \\
\text { żołądka }\end{array}$ & $\begin{array}{c}\text { Docetaxel, cisplatin, fluorouracil/ } \\
\text { Docetaksel, cisplatyna, fluorouracyl }\end{array}$ & 75 & $0.7 \%$ \\
\hline
\end{tabular}

paratus lesions are characteristic for some groups of cytotoxic agents, including taxanes, and not the prostatic cancer treated with them, and hence, periungual lesions are observed in docetaxel therapies used in patients that are treated due to other often diagnosed and treated cancers, e.g. breast or lung cancer. The incidence in grade 3-4 according to CTC is similar to the case of the prostatic cancer (table 1) [1].

\section{OBJECTIVE}

The aim of the article is to present clinical cases of patients treated with chemotherapy involving docetaxel who experienced periungual lesions, and to show treatment methods from a dermatologist's perspective.

\section{CLINICAL PRESENTATION OF PERIUNGUAL LESIONS}

Periungual lesions are a common chemotherapy complication caused by cytotoxic agents' effects on fast dividing cells. They appear not only during classic chemotherapy, but also during a common in oncology therapy with epidermal growth factor receptors (EGFRs), including antibodies (cetuximab, panitumumab), or tyrosine kinase receptor inhibitors (TKI; e.g. erlotinib, gefitinib). The most popular nail apparatus lesions observed during the treatment of neoplasms include onycholysis, leukonychia, melanonychia, onychomadesis, Beau's lines, and periungual lesions [8].

CTC v. 4.0 is a commonly used scoring tool assessing treatment toxicity. For the majority of adverse duktu leczniczego należy zmniejszyć i/lub odroczyć podanie kolejnego cyklu chemioterapii do momentu zmniejszenia nasilenia działań niepożądanych do poziomu umożliwiającego kontynuowanie terapii. Zmiany w obrębie aparatu paznokciowego są charakterystyczne dla pewnych grup cytostatyków, w tym dla taksanów, a nie dla leczonego z ich wykorzystaniem raka gruczołu krokowego, dlatego zmiany okołopaznokciowe obserwuje się w przebiegu terapii docetakselem u pacjentów leczonych także z powodu innych, często diagnozowanych i leczonych nowotworów, takich jak rak piersi czy płuca. Częstość ich występowania w stopniu 3.-4. wg CTC jest podobna jak w raku gruczołu krokowego (tab. 1) [1].

\section{CEL PRACY}

Celem pracy jest zaprezentowanie przypadków klinicznych pacjentów leczonych chemioterapią docetakselem, u których wystąpiły zmiany okołopaznokciowe, a także metod leczenia z punktu widzenia dermatologa.

\section{OBRAZ KLINICZNY ZMIAN APARATU PAZNOKCIOWEGO}

Zmiany aparatu paznokciowego są częstym powikłaniem chemioterapii i stanowią efekt działania cytostatyków na szybko dzielące się komórki. Powstają nie tylko w przebiegu klasycznej chemioterapii, lecz także powszechnie stosowanej w onkologii terapii inhibitorami receptora dla naskórkowego czynnika wzrostu (epidermal growth factor receptor - EGFR), w tym przeciwciałami (cetuksymab, panitumumab) czy inhibitorami 
events it is a five-grade scoring system (from G1 to G5), where G1 is the lowest (usually low clinical significance) level of severity of a given adverse event, and G4 is the highest level that is also often life-threatening. G5 is always death caused by the adverse event. For nail apparatus toxicity, CTC v. 4.0 includes nail plate loss, dislocations, and nail ridging. The scale for nail plate loss (onycholysis) is two-grade and includes asymptomatic (grade 1) and symptomatic (grade 2) detachment of the nail plate from the nail bed or a complete nail loss. When lesions limit everyday activities, they are classified as grade 2 . At the moment there are no standards regarding how to deal with the described complications [9]. In order to understand their pathomechanism correctly, anatomy and physiology of the nail apparatus should be taken into account.

Nail apparatus consists of the matrix, nail plate, nail bed, lateral nail walls, proximal nail wall, and eponychium. The nail plate is a cornified skin appendage. The matrix is the site of its growth. As opposed to hair, nails do not have a growth cycle, but grow continually, what is significant for the development and the course of complications caused by cytotoxic drugs. Fingernail plate grows $0.5-1.2 \mathrm{~mm}$ per week, and consequently, a new nail grows in about 46 months. In case of toenail plates, the process is three times slower, and a completely new nail grows in about 12-18 months. Concurrent vascular disorder, especially arteriosclerosis at an elderly age, may delay the process.

Ungual lesions occurring in patients treated with taxanes may be divided into several groups. Hyperpigmentation of nails, Beau's lines and slow growth of nail plates are most commonly observed after the use of cytotoxic drugs [8].

\section{Hyperpigmentation of nail plates}

Hyperpigmentation of the nail plate may regard the nail surface, its internal layer, or be found under the nail plate.

Melanonychia is a dark hyperpigmentation of the nail. It is usually observed after about $1-2$ months after commencing the treatment. It may take the form of longitudinal dark streaks (melanonychia striata) or cover the entire surface. Probably, melanocyte activation is the reason behind such lesions, however, the pathomechanism is not fully known. In case of taxanes, also orange hyperpigmentations are described, and those result from small micro-haemorrhages from the nail matrix (fig. 1).

Leukonychia is a white hyperpigmentation of the nail plate. It is suggested to divide leukonychia secondary to the treatment with cytotoxic drugs into true and apparent. True leukonychia results from keratinization disorders of the distal matrix and ma- kinaz tyrozynowych (tyrosine kinase receptor inhibitor TKI, np. erlotynib, gefitynib). Do najczęstszych zmian aparatu paznokciowego obserwowanych podczas leczenia nowotworów należą: onycholiza, leukonychia, melanonychia, onychomadesis, linie Beau oraz zmiany okołopaznokciowe [8].

Skala CTC v. 4.0 jest powszechnie używana do oceny toksyczności leczenia. Dla większości działań niepożądanych jest skalą pięciostopniową (od G1 do G5), gdzie G1 oznacza najmniejszy (najczęściej mało istotny klinicznie) poziom nasilenia określonego działania niepożądanego, a G4 najwyższy, często zagrażający życiu. G5 zawsze oznacza zgon będący skutkiem działania niepożądanego. Skala CTC v. $4.0 \mathrm{w}$ odniesieniu do toksyczności dotyczącej aparatu paznokciowego obejmuje utratę płytek paznokci, przemieszczenia oraz pofałdowania płytki paznokci (nail ridging). Dla utraty płytek paznokci (onycholysis) skala jest dwustopniowa i obejmuje bezobjawowe (w stopniu pierwszym) oraz objawowe (w stopniu drugim) oddzielenie płytki paznokciowej od łożyska paznokcia lub całkowitą utratę paznokcia. Zmiany ograniczające codzienną aktywność klasyfikuje się do stopnia drugiego. Obecnie nie ma standardu postępowania z opisywanymi powikłaniami [9].

Aby zrozumieć patomechanizm ich powstania, należy wziąć pod uwagę anatomię i fizjologię aparatu paznokciowego. Aparat paznokciowy składa się z macierzy, płytki paznokciowej, łożyska, wałów bocznych, wału przyśrodkowego i obrąbka (eponychium). Płytka paznokciowa jest zrogowaciałym przydatkiem skóry, a macierz to miejsce jej wzrostu. W odróżnieniu od włosów paznokcie nie mają cyklu wzrostu, lecz rosną w sposób ciągły, co ma istotne znaczenie w rozwoju i przebiegu powikłań po lekach cytostatycznych. Płytka paznokcia ręki wzrasta 0,5-1,2 mm tygodniowo, dlatego nowy paznokieć odrasta przez ok. 4-6 miesięcy. W przypadku płytki paznokcia stopy proces ten przebiega trzykrotnie wolniej, a nowy paznokieć odrasta całkowicie po ok. 12-18 miesiącach. Współistniejące zaburzenia naczyniowe, zwłaszcza miażdżyca w wieku starszym, mogą opóźnić ten proces.

Zmiany paznokciowe występujące u pacjentów leczonych taksanami można podzielić na kilka grup. Najczęściej po lekach cytotoksycznych obserwuje się zmiany zabarwienia paznokci, linie Beau oraz spowolnienie wzrostu płytek paznokciowych [8].

\section{Zmiany zabarwienia płytek paznokciowych}

Zmiana barwy płytki paznokciowej może dotyczyć powierzchni płytki, jej wewnętrznej warstwy lub znajdować się pod płytką paznokciową.

Melanonychia to ciemne przebarwienia paznokcia. Zazwyczaj obserwuje się je ok. 1-2 miesięcy po rozpoczęciu leczenia. Może mieć postać linijnych przebarwień (melanonychia striata) lub zajmować całą powierzchnię. Przyczyną powstania takich zmian jest prawdopodobnie aktywacja melanocytów, jednak patomechanizm 

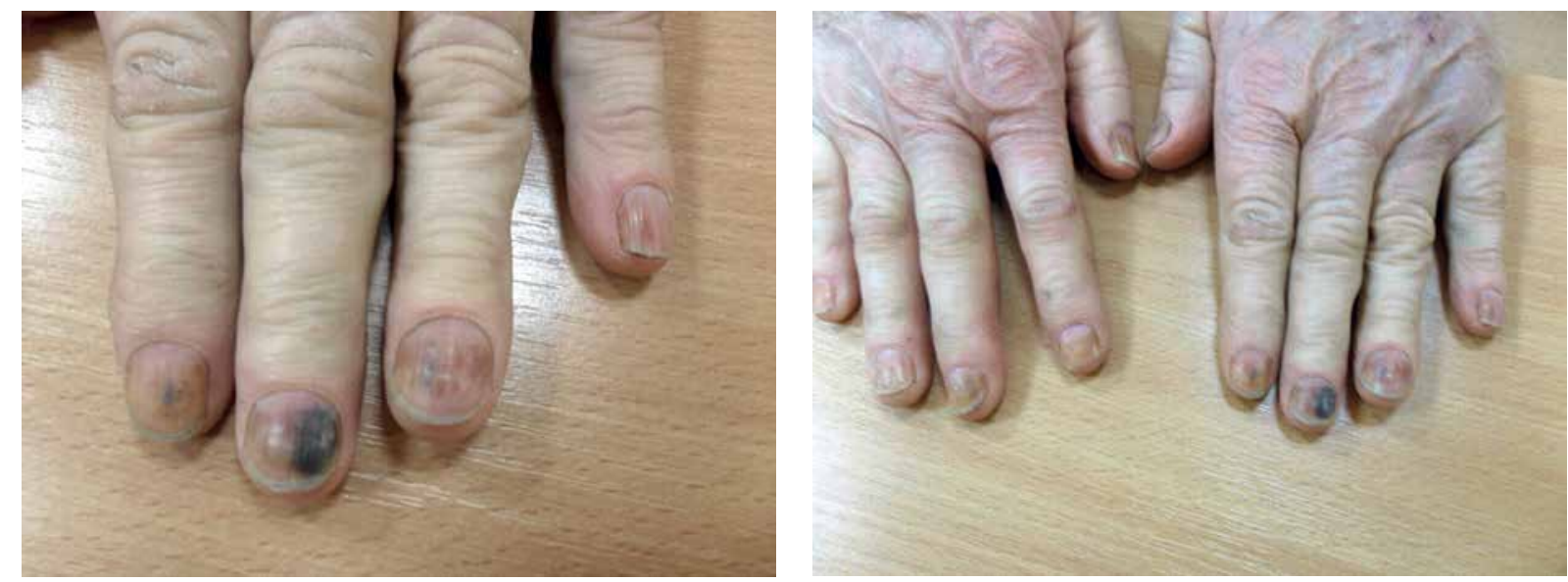

Figure I. Melanonychia in patients treated with docetaxel

Rycina I. Melanonychia u pacjentów leczonych docetakselem

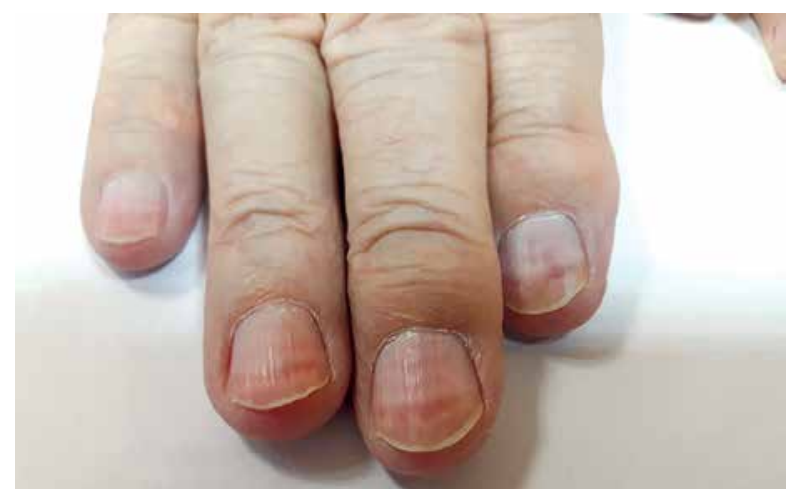

Figure 2. Partial leukonychia

Rycina 2. Częściowa leukonychia

nifests itself with white transverse streaks that move distally as the nail grows. Apparent leukonychia results from dysfunctions of blood flow in the nail bed, and it does move as the nail grows [8, 10, 11] (fig. 2).

Three forms of apparent leukonychia have been separated:

- half and half nails - half of the nail plate is chalkwhite, and the other half is of natural colour,

- Muehrcke's nails - white bands that are parallel to the distal rim of the nail,

- Terry's nails - nails are chalk-white, the lunula is invisible, and a couple of millimetres at the distal end are of natural pinkish colour.

Often leukonychia and melanonychia are observed in the same patients both on different and the same nails.

\section{Beau's lines}

Those are indentations in the nail plate that appeared due to a temporary cessation of mitotic activity in the nail matrix. Their residual from is nail shedding (onychomadesis), when the nail plate becomes completely separated from the matrix and the bed; it nie został dobrze poznany. W przypadku taksanów opisuje się także przebarwienia pomarańczowe wynikające z drobnych mikrokrwawień z łożyska paznokcia (ryc. 1).

Leukonychia (bielactwo paznokci) to zmiana zabarwienia płytki paznokciowej na białą. Proponuje się podział bielactwa paznokci w przebiegu leczenia cytostatykami na prawdziwe i pozorne. Prawdziwa leukonychia wynika z zaburzeń keratynizacji dystalnej części macierzy paznokci i objawia się poprzecznymi białymi pasmami, które przesuwają się dystalnie wraz ze wzrostem paznokci. Pozorna leukonychia wynika raczej z zaburzeń przepływu krwi w łożysku i w takim przypadku nie widać przesuwania się zmiany podczas wzrostu paznokcia [8, 10, 11] (ryc. 2).

Wyodrębniono trzy postaci pozornej leukonychii: - paznokcie pół na pół (paznokcie half and half) - połowa płytki paznokcia jest kredowobiała, a połowa prawidłowej barwy,

- pasma Muehrckego - białe prążki równoległe do dystalnego brzegu paznokcia,

- paznokcie Terry'ego - paznokcie są kredowobiałe, lunula jest niewidoczna, a dystalna kilkumilimetrowa część ma prawidłowe, różowe zabarwienie. 
usually ends in a nail loss. If drugs are administered at intervals as opposed to continual therapy, several Beau's lines may be observed on one nail plate - they present periods when the drugs were used.

\section{Onycholysis}

Onycholysis, i.e. partial separation of the nail plate from the matrix, is observed in case of treatment involving taxanes (fig. 2). The reason is nail matrix damage. Total damage of the matrix epithelium (epidermolysis) may lead to development of a haemorrhagic blister under the nail plate and cause painful shedding of the nail plate (onychomadesis). The phenomenon is especially common during the treatment with docetaxel [12-14]. A so-called PATEO (periarticular thenar erythema with onycholysis) syndrome was recognized; it is characterized by onycholysis with concurrent erythematous lesions on the dorsal side of the hand, and areas of the Achilles tendon as well as ankle joints caused by the treatment with taxanes [15] (fig. 3).

\section{PROPHYLAXIS AND TREATMENT}

The majority of ungual lesions observed during treatments with cytotoxic agents do not require treatment, because they usually subside after the given drug is discontinued. Given the fact that in some patients the lesions may exert a negative influence on the life comfort, which is already low due to the underlying disease and its treatment, the risk of developing such lesions should be minimized.

In 2015 "The Lancet Oncology" journal presented several simple guidelines for the prophylaxis of adverse events regarding nails of patients who start chemotherapy (table 2) [8].

Ungual lesions caused by docetaxel proved to be such a significant clinical problem that a study was conducted, in which patients receiving docetaxel every 3 weeks put their right hand for 90 minutes

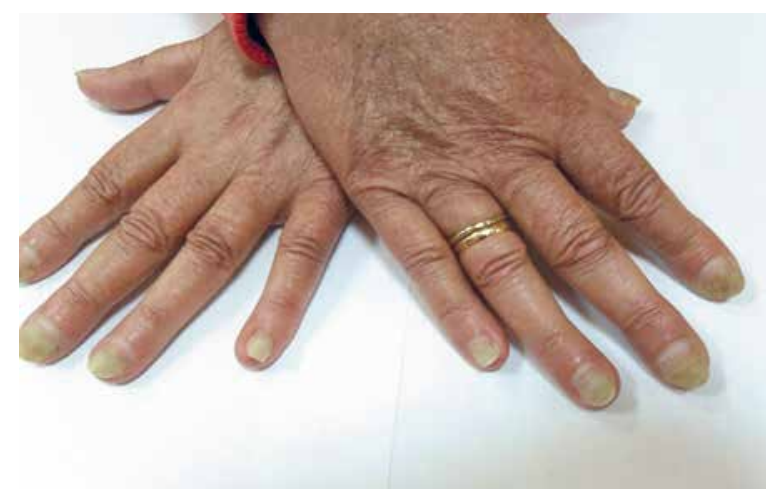

Figure 3. Onycholysis in patients treated with docetaxel Rycina 3. Onycholiza u pacjentów leczonych docetakselem
Nierzadko obserwuje się występowanie leukonychii i melanonychii u tych samych pacjentów zarówno na różnych, jak i tych samych paznokciach.

\section{Linie Beau}

Są to linijne zagłębienia płytki paznokciowej powstające wskutek przejściowego zahamowania aktywności mitotycznej macierzy paznokcia. Zejściową ich postacią jest złuszczanie płytki paznokciowej (onychomadesis), kiedy dochodzi do całkowitego oddzielenia się płytki paznokciowej od macierzy oraz łożyska i zazwyczaj kończy się utratą paznokcia. W przypadku podawania leków w cyklach przerywanych, a nie w terapii ciągłej, można obserwować na jednej płytce paznokciowej kilka linii Beau reprezentujących okresy stosowania leków.

\section{Onycholiza}

W przypadku leczenia taksanami na paznokciach obserwuje się onycholizę, czyli częściowe oddzielenie się płytki paznokciowej od macierzy paznokcia (ryc. 2). Przyczyną jest uszkodzenie macierzy paznokcia. Całkowite uszkodzenie nabłonka macierzy paznokcia (epidermoliza) może prowadzić do powstania krwotocznego pęcherza zlokalizowanego pod płytką paznokciową i powodować bolesne złuszczenie płytki (onychomadesis). Zjawisko to jest szczególnie często obserwowane podczas leczenia docetakselem [12-14]. Wyróżnia się tzw. zespół PATEO (periarticular thenar erythema with onycholysis), charakteryzujący się onycholizą z towarzyszącymi zmianami rumieniowymi na grzbietowych częściach rąk oraz w okolicy ścięgna Achillesa i stawów skokowych związany z leczeniem taksanami [15] (ryc. 3).

\section{PROFILAKTYKA I LECZENIE}

Większość zmian paznokciowych obserwowanych podczas terapii cytostatykami nie wymaga leczenia, ponieważ ustępuje po odstawieniu cytostatyku. Ze 
Table 2. Guidelines for patients during chemotherapyw

Tabela 2. Zalecenia dla pacjentów w trakcie chemioterapii

\begin{tabular}{l}
\hline Avoid repeated injuries, friction, and pressure exerted on nails (manicure; nail biting)/Unikaj powtarzających się urazów, tarcia, ucisku \\
na paznokcie (manicure, obgryzanie paznokci) \\
\hline Wear cotton gloves to protect the fingertips, and vinyl gloves during activities that would require prolonged contact with water \\
(e.g. washing the dishes)/Używaj rękawiczek bawełnianych na opuszki palców oraz winylowych podczas czynności związanych \\
z przedłużonym kontaktem z wodą (np. mycie naczyń) \\
\hline Do not use detergent, and substances toxic for nails (toluene, formaldehyde) as well as nail polish removers/Nie używaj detergentów, \\
substancji toksycznych dla paznokci (toluen, formaldehyd) oraz zmywaczy do paznokci \\
\hline Cut your nails regularly, shortly, and smoothly/Regularnie, krótko i gładko obcinaj paznokcie \\
\hline Apply emollients to the entire nail apparatus. Also, it is recommended to use nail enamels that decrease water loss/Stosuj emolienty \\
na cały aparat paznokciowy. Wskazane jest również stosowanie lakierów do paznokci zmniejszających utratę wody \\
\hline Wear soft non-compression cotton socks/Noś bawełniane, miękkie, nieuciskające skarpety
\end{tabular}

into a special cooling glove that had a temperature of $-30^{\circ} \mathrm{C}$ during the cytotoxic agent transfusion. The procedure decreased the appearance of G1 and G2 nail apparatus lesions as compared with the left hand from $51 \%$ to $11 \%[16,17]$.

In case of painful onycholysis caused by appearance of subungual haematomata, fast treatment is necessary due to severe pain. Subungual haematomata covering small nail areas are removed by puncturing the nail plate in order to release the blood accumulated under the plate. The authors suggest the use of thick needles (16-20G) that are screwed in with a screw motion. The procedure does not require anaesthesia and brings patients immediate relief. However, when the haematoma covers the majority of the nail, surgical removal of the nail plate appears to be the only treatment method.

In case of a superinfection of the free space that appeared due to onycholysis or quite common paronychia, i.e. bacterial infection of the nail walls, disinfectants including octenidine or topical antibiotics should be added to the treatment. When the reaction in the surrounding subcutaneous tissue is severe, oral antibiotics need to be considered.

Some authors believe that the use of biotin during the treatment may prove to be beneficial in prophylaxis of nail lesion development. Yet, studies in this area are not sufficient [18].

\section{CONCLUSIONS}

Chemotherapy with taxoids (including docetaxel) is often used in oncology for the treatment of prostatic cancer, and other malignant neoplasms. As discussed, the number of administered units in the prostatic cancer translates into patients' lifetime, and thus, administration of a maximal possible docetaxel dose is aimed at, and consequently, proper prevention względu na to, że u niektórych pacjentów zmiany te wpływają na komfort życia, który i tak jest obniżony z powodu choroby zasadniczej i jej leczenia, należy zadbać o zminimalizowanie ryzyka ich wystąpienia.

W 2015 roku w czasopiśmie "Lancet Oncology" przedstawiono kilka prostych zaleceń dotyczących profilaktyki działań niepożądanych w obrębie paznokci dla pacjentów rozpoczynających chemioterapię (tab. 2) [8].

Zmiany paznokciowe wywoływane przez docetaksel okazały się na tyle istotnym problemem klinicznym, że przeprowadzono badanie, w którym pacjenci otrzymujący docetaksel co 3 tygodnie podczas wlewu cytostatyku wkładali prawą rękę na 90 minut do specjalnej chłodzącej rękawiczki o temperaturze $-30^{\circ} \mathrm{C}$. Zabieg ten ograniczył powstawanie zmian aparatu paznokciowego w stopniu G1 i G2 w porównaniu z lewą ręką - z 51\% do $11 \%$ [16, 17].

W przypadku bolesnej onycholizy spowodowanej powstawaniem krwiaków podpaznokciowych szybkie leczenie jest niezbędne w związku z silnymi dolegliwościami bólowymi. Krwiaki podpaznokciowe zajmujące niewielkie obszary paznokcia usuwa się przez przekłucie płytki paznokciowej w celu umożliwienia odpływu gromadzącej się pod płytką krwi. Autorzy proponują zastosowanie grubej igły (1620 G) i wkręcanie jej ruchem śrubowym. Zabieg ten nie wymaga znieczulenia i przynosi pacjentom natychmiastową ulgę. Jeśli jednak krwiakiem objęta jest większa część paznokcia, jedyną metodą leczenia jest chirurgiczne usunięcie płytki paznokciowej.

W przypadku nadkażenia wolnej przestrzeni powstałej na skutek onycholizy lub nierzadko spotykanej zanokcicy, czyli bakteryjnej infekcji wałów paznokciowych, do leczenia warto dołączyć środki dezynfekujące, takie jak oktenidyna, lub antybiotyki stosowane miejscowo. W przypadku dużego odczynu w otaczającej tkance podskórnej należy rozważyć antybiotykoterapię doustną. 
means and treatment of concurrent adverse events, including nail apparatus lesions, is of key importance. The aim of palliative treatment is to prolong survival of terminally ill patients with simultaneous maintenance of the comfort and quality of their life periungual lesions lower both of them. Furthermore, patients suffering from skin lesions that undergo oncological treatment constitute an increasing percentage of the ill that come to the dermatologist's. Thus, knowledge about adverse events should be widespread among oncologists and dermatologists.

\section{CONFLICT OF INTEREST}

The authors declare no conflict of interest.
Niektórzy autorzy uważają, że stosowanie biotyny w trakcie leczenia może okazać się korzystne w profilaktyce powstawania zmian paznokciowych. Badania $\mathrm{w}$ tej kwestii są jednak jeszcze niewystarczające [18].

\section{WNIOSKI}

Chemioterapia z wykorzystaniem taksoidów (w tym docetakselu) jest często stosowana w onkologii, w leczeniu raka prostaty, ale też innych nowotworów złośliwych. Jak wspomniano, w raku prostaty liczba podań przekłada się na długość życia pacjentów i dąży się do podania maksymalnej możliwej dawki docetakselu, dlatego tak ważna jest odpowiednia profilaktyka i leczenie towarzyszących działań niepożądanych, również dotyczących aparatu paznokciowego. Celem leczenia paliatywnego jest wydłużenie przeżycia nieuleczalnie chorych przy zachowaniu jak najlepszego komfortu i jakości życia, a zmiany aparatu paznokciowego są przyczyną ich pogorszenia. Ponadto chorzy ze zmianami skórnymi występującymi w trakcie terapii onkologicznej stanowią coraz większy odsetek pacjentów zgłaszających się do gabinetów dermatologicznych. Dlatego wiedza na temat tych działań niepożądanych powinna być powszechna wśród onkologów i dermatologów.

\section{KONFLIKT INTERESÓW}

Autorzy nie zgłaszają konfliktu interesów.

\section{References}

\section{Piśmiennictwo}

1. Taxotere. Charakterystyka produktu leczniczego. Accessed on 15.08.2019. https://www.ema.europa.eu/en/documents/ product-information/taxotere-epar-product-information_pl.pdf

2. Wojciechowska U., Didkowska J.: Zachorowania i zgony na nowotwory złośliwe w Polsce. Krajowy Rejestr Nowotworów, Centrum Onkologii - Instytut im. Marii Skłodowskiej-Curie. Available at: http://onkologia.org.pl/raporty/ dostęp z dnia 15.08.2019.

3. Pernar C.H., Ebot E.M., Wilson K.M., Mucci L.A.: The epidemiology of prostate cancer. Cold Spring Harb Perspect Med 2018, 8, a030361.

4. Tannock I.F., de Wit R., Berry W.R., Horti J., Pluzanska A., Chi K.N., et al.: Docetaxel plus prednisone or mitoxantrone plus prednisone for advanced prostate cancer. N Engl J Med 2004, 351, 1502-1512.

5. Shen Y.C., Chiang P.H., Luo H.L., Chuang Y.C., Chen Y.T., Kang C.H., et al.: Determine of the optimal number of cycles of docetaxel in the treatment of metastatic castration-resistant prostate cancer. Kaohsiung J Med Sci 2016, 32, 458-463.

6. Sweeney C.J., Chen Y.H., Carducci M., Liu G., Jarrard D.F., Eisenberger M., et al.: Chemohormonal therapy in metastatic hormone-sensitive prostate cancer. N Engl J Med 2015, 373, 737-746.

7. James N.D., Sydes M.R., Clarke N.W., Mason M.D., Dearnaley D.P., Spears M.R., et al.: Addition of docetaxel, zoledronic acid, or both to first-line long-term hormone therapy in prostate cancer (STAMPEDE): survival results from an adaptive, multiarm, multistage, platform randomised controlled trial. Lancet 2016, 387, 1163-1177.

8. Robert C., Sibaud V., Mateus C., Verschoore M., Charles C., Lanoy E., et al.: Nail toxicities induced by systemic anticancer treatments. Lancet Oncol 2015, 16, e181-e189.

9. N. Cancer Institute: “Common Terminology Criteria for Adverse Events (CTCAE) Common Terminology Criteria for Adverse Events v4.0 (CTCAE)." 2009. Accessed on 15.08.2019.

10. Antonarakis E.S.: Acquired leukonychia totalis. N Engl J Med 2006, 355, e2.

11. Lehoczky O., Pulay T.: Transverse leukonychia secondary to paclitaxel-carboplatin chemotherapy in a patient with ovarian cancer. J Obstet Gynaecol 2002, 22, 694. 
12. Chen G.Y., Chen W., Huang W.T.: Single transverse apparent leukonychia caused by 5-fluorouracil plus leucovorin. Dermatology 2003, 207, 86A-87A.

13. Cunningham D., Gilchrist N.L., Forrest G.J., Soukop M.: Onycholysis associated with cytotoxic drugs. Br Med J 1985, 290, 675-676.

14. Hussain M., Fizazi K., Saad F., Rathenborg P., Shore N., Ferreira U., et al.: Enzalutamide in men with nonmetastatic, castration-resistant prostate cancer. N Engl J Med 2018, 378, 2465-2474.

15. Lau C.P., Hui P., Chan T.C.: Docetaxel-induced nail toxicity: a case of severe onycholysis and topic review. Chin Med J 2011, $124,2559-2560$.

16. Scotté F., Tourani J.M., Banu E., Peyromaure M., Levy E., Marsan S., et al.: Multicenter study of a frozen glove to prevent docetaxel-induced onycholysis and cutaneous toxicity of the hand. J Clin Oncol 2005, 23, 4424-4429.

17. Can G., Aydiner A., Cavdar I.: Taxane-induced nail changes: predictors and efficacy of the use of frozen gloves and socks in the prevention of nail toxicity. Eur J Oncol Nurs 2012, 16, 270-275.

18. Scheinfeld N., Dahdah M.J., Scher R.: Vitamins and minerals: their role in nail health and disease. J Drugs Dermatol 2007, 6, 782-787.

Received: 15.01 .2019

Accepted: 19.10 .2019

Otrzymano: $15.01 .2019 \mathrm{r}$.

Zaakceptowano: $19.10 .2019 \mathrm{r}$.

How to cite this article

Sigorski D., Markiewicz A., Owczarczyk-Saczonek A.B., Różanowski P., Kułakowska A., Lebiedzińska A., Placek W.J.: Periungual lesions secondary to chemotherapy with docetaxel. Dermatol Rev/Przegl Dermatol 2019, 106, 646-655.

DOI: https://doi.org/10.5114/dr.2019.92737. 